\title{
Production of MgO-X Refractory Material with Cellular Matrix by Colloidal Processing
}

\section{Wagner da Silveira, Guido Falk}

Department of Powder Technology for Glass and Ceramics, Saarland University, Saarbrücken, Germany.

Email: g.falk@nanotech.uni-saarland.de

Received October $5^{\text {th }}, 2012$; revised November $7^{\text {th }}, 2012$; accepted November $4^{\text {th }}, 2012$

\begin{abstract}
The production in the siderurgy and foundry industry has changed considerably in the past years. Despite the new technologies and process, the use of magnesia carbon refractory remains constant. Namely the magnesia carbon refractory is widely used due low-priced cost, high refractivity, excellent corrosion resistance, thermal shock resistance, low thermal expansion, high slag penetration resistance and low wettability. The main disadvantages of use magnesia carbon refractories are the high carbon oxidation susceptibility and the formation $\mathrm{CO}$ and $\mathrm{CO}_{2}$ gases. As a result, tonne of $\mathrm{CO}$ and $\mathrm{CO}_{2}$ are expelled to the atmosphere. The use of open cell carbon-foam magnesia composite for refractory application can offer a substitute for the traditional refractory material since the high carbon content can be minored and the low mechanical strength and poor oxidation resistance of these materials can be improved.
\end{abstract}

Keywords: Carbon; Refractory; $\mathrm{MgO}$; Oxidation

\section{Introduction}

Magnesia-carbon refractories with open cell carbon foam matrices and magnesia space filling microstructures are offering interesting potentials addressing ecological and economical issues in the steel making industry supposed low mechanical strength and poor oxidation resistance of these materials could be improved.

Magnesia-carbon refractory materials (MgO-C-X) is extensively used in steel making industry, mainly in steel ladles, basic oxygen (LD) converters, electric arc furnaces and also in secondary steel making production. Mainly because of its good compatibility, high refractivity, excellent corrosion resistance, thermal shock resistance, low thermal expansion, high slag penetration resistance and low wettability. The successful performance of magnesia carbon bricks came in for interest to develop novel carbon-containing refractories ( $\mathrm{MgO}-\mathrm{C}-\mathrm{X}, \mathrm{Al}_{2} \mathrm{O}_{3}$ $\mathrm{C}$ and $\mathrm{Al}_{2} \mathrm{O}_{3}$-SiC-C) at elevated carbon concentrations.

In magnesia-carbon refractory materials usually is used a carbon content of $8 \mathrm{wt} \%-20 \mathrm{wt} \%$. The function of the carbon is to seal the porous structure, improve the slag and metal corrosion due to non-wetting character and improvement of thermal shock resistance due to high thermal conductivity and low thermal expansion characteristics. However, the carbon incorporation in the refractory bricks suffers two main drawbacks, low mechanical strength and high carbon oxidation susceptibil- ity at high temperatures.

A formation of a dense layer of $\mathrm{MgO}$ at the operational surface of $\mathrm{MgO}-\mathrm{C}-\mathrm{X}$ brick, due to oxidation of $\mathrm{Mg}$ (produced on reaction between $\mathrm{MgO}$ and $\mathrm{C}$ ) limit the penetration of slag and metal components and by this means further improves the penetration and corrosion resistance. Carbon suffers from reduced oxidation resistance and can oxidize to form $\mathrm{CO}$ and $\mathrm{CO}_{2}$ resulting in a porous structure with poor strength and corrosion resistance. Prevention of carbon oxidation is done by using antioxidants, which reacts with external oxygen, gets oxidized and protects carbon, consequently retaining the brick structure and properties.

The immediate consequence of carbon oxidation is the decrease of mechanical strength associated with considerable porosity increase, which reduces the resistance to air and slag penetration. The benefits of the carbon addition in refractories depend on the oxidation control under operational conditions. Additionally use of carbon in refractory will increase the generation of $\mathrm{CO}$ and $\mathrm{CO}_{2}$ gases and consequently possibly will become a concern for global environment. For this reason, the researchers are considering and working for reduction in the total amount of carbon in MgO-C-X brick without compromising with the final characteristics. Taking into account the world steel industry the oxidation of the carbon in the refractory bricks can produce over two billion tons of $\mathrm{CO}_{2}$. 
Open cell carbon foam-Mg composites for refractory applications are offering interesting potentials addressing ecological and economical issues in the steel making industry supposed low mechanical strength and poor oxidation resistance of these materials could be improved.

\section{Oxidation in Refractory Materials-A Literature Review}

The direct oxidation of carbon with the oxygen $\left(\mathrm{O}_{2}\right)$ elapses between $400^{\circ} \mathrm{C}$ and $1200^{\circ} \mathrm{C}$ and oxygen partial pressure in the range higher than $10^{-4}$ mbar (Equation (1)).

$$
2 \mathrm{C}(\mathrm{s})+\mathrm{O}_{2}(\mathrm{~g}) \rightarrow 2 \mathrm{CO}(\mathrm{g})
$$

At temperatures exceeding $1400^{\circ} \mathrm{C}$ indirect oxidation occurs and becomes predominant. Carbon reacts with oxides or liquids incorporated in the system [1-4]. An alternative control of carbon oxidation in refractory bricks would be covering the carbon particles surface with protection layers of specific oxides $\left(\mathrm{Al}_{2} \mathrm{O}_{3}, \mathrm{SiO}_{2}\right.$, $\mathrm{TiO}_{2}$, and $\mathrm{ZrO}_{2}$ ) or carbides $(\mathrm{SiC})$.

Selected oxides, such as $\mathrm{ZrO}_{2}$ and $\mathrm{TiO}_{2}$, in presence of carbon, serve as electron donators and transfer electrons to carbon phase, generating a stable electronic distribution and thereby inhibit carbon oxidation [5].

The coated carbon has better oxidation resistance; however studies reveal that this effect is limited at higher temperatures and specific boundary conditions. Moreover, the weak interlinkage between carbon and the coated layer, results in poor strength and crack propagation resistance [2]. Another effective way to prevent oxidation of carbon-containing refractories is using antioxidants. The anti-oxidants react with carbon phase and thereby contribute to degrease of carbon oxidation rate. Some of the products formed after the reactions of the carbon phase with anti-oxidant reveal volumetric expansion. The porosity of the carbon-containing refractory is reduced and, the same is true for the permeability and oxygen diffusion in the refractory.

The most used anti-oxidants are metallic powders (Al, $\mathrm{Mg}$, and $\mathrm{Si})$, carbides $\left(\mathrm{SiC}, \mathrm{B}_{4} \mathrm{C}\right)$, borates $\left(\mathrm{ZrB}_{2}, \mathrm{CaB}_{2}\right)$ or a combination of those materials.

The selection of the anti-oxidant substance depends on the refractory matrix material. For example, metallic powder of $\mathrm{Mg}$ and $\mathrm{Al}$ are usually added to $\mathrm{MgO}-\mathrm{C}$ refractory bricks, while $\mathrm{SiC}$ and $\mathrm{B}_{4} \mathrm{C}$ are used in $\mathrm{Al}_{2} \mathrm{O}_{3}-\mathrm{C}$ refractory bricks [6]. Some works have been published aiming to understand the behaviour of selected anti-oxidants, however the majority of these studies had been carried out for the MgO-C system [7,8]. Each anti-oxidant substance acts at different operating temperatures, the use of more than one type of anti-oxidant substance can complement the action of these materials in terms of prevention of the carbon oxidation.

\subsection{Metallic Antioxidants}

The powder of $\mathrm{Al}, \mathrm{Mg}$, Si and the alloys of these materials are often used as anti-oxidant substances due to the low cost and effective protection that increase the strength and oxidation resistance of the refractory material. However, the use in carbon refractory materials is limited by the strong tendency to react with water [7,9]. In attempt to use the metallic powder, different superficial treatment methodologies have been proposed in the literature to inhibit reaction with water. A recommended treatment consists in use of alcoxide metals as precursors to obtain an oxide coating $\left(\mathrm{Al}_{2} \mathrm{O}_{3}, \mathrm{SiO}_{2}, \mathrm{TiO}_{2}\right)$ onto the surface of the metallic powder [10]. The main disadvantage is the insufficient adhesion between the metallic powder and the oxide layer $\left(\mathrm{Al}_{2} \mathrm{O}_{3}, \mathrm{SiO}_{2}, \mathrm{TiO}_{2}\right)$. The oxide layer is easily detached from the surface of these materials, allowing the water contact and hydrogen generation.

\subsubsection{Aluminum}

The use of aluminum as anti-oxidant is given in the state of the art $[9,11]$. In these works a consensus exists in terms of excellent quantity of Al to be added to the refractory bricks. The following aspects have to be considered: the particles, the refractory processing stages and the initial porosity.

The behaviour of aluminum powder as anti-oxidant has been investigated in $\mathrm{MgO}-\mathrm{C}$ refractories, and these studies defined the order of reaction $[9,12]$ : The metallic $\mathrm{Al}$ oxidate quickly after the refractory preparation process, forming a layer of $\mathrm{Al}_{2} \mathrm{O}_{3}$ (Equation (2)).

$$
4 \mathrm{Al}(\mathrm{s})+3 \mathrm{O}_{2}(\mathrm{~g}) \rightarrow 2 \mathrm{Al}_{2} \mathrm{O}_{3}(\mathrm{~s})
$$

At Al melting temperature of $660^{\circ} \mathrm{C}$, a thin layer of $\mathrm{Al}_{2} \mathrm{O}_{3}$ is trapping the $\mathrm{Al}$ liquid for a while, until the thin layer will break, releasing the melted $\mathrm{Al}$. The melted $\mathrm{Al}$ will react with carbon to form $\mathrm{Al}_{4} \mathrm{C}_{3}$ (Equation (3)), that later will be able to be react with atmospheric nitrogen forming the AlN phase (Equation (4)).

$$
\begin{gathered}
4 \mathrm{Al}(1, \mathrm{~g})+3 \mathrm{C}(\mathrm{s}) \rightarrow \mathrm{Al}_{4} \mathrm{C}_{3}(\mathrm{~s}) \\
\mathrm{Al}_{4} \mathrm{C}_{3}(\mathrm{~s})+2 \mathrm{~N}_{2}(\mathrm{~g}) \rightarrow 4 \mathrm{AlN}(\mathrm{s})+3 \mathrm{C}(\mathrm{s})
\end{gathered}
$$

At a temperature of $1100^{\circ} \mathrm{C}$ the $\mathrm{Al}_{4} \mathrm{C}_{3}$ and the $\mathrm{AlN}$ will react with the $\mathrm{CO}(\mathrm{g})$, present in the refractory brick, to form $\mathrm{Al}_{2} \mathrm{O}_{3}$ (Equations (5)-(7)).

The $\mathrm{Al}_{2} \mathrm{O}_{3}$ formed will react with the refractory $\mathrm{MgO}$ to form spinel $\mathrm{MgAl}_{2} \mathrm{O}_{4}$ (Equation (7)).

$$
\begin{gathered}
\mathrm{Al}_{4} \mathrm{C}_{3}(\mathrm{~s})+6 \mathrm{CO}(\mathrm{g}) \rightarrow 2 \mathrm{Al}_{2} \mathrm{O}_{3}(\mathrm{~s})+9 \mathrm{C}(\mathrm{s}) \\
2 \mathrm{AlN}(\mathrm{s})+3 \mathrm{CO}(\mathrm{g}) \rightarrow \mathrm{Al}_{2} \mathrm{O}_{3}(\mathrm{~s})+\mathrm{N}_{2}(\mathrm{~g})+3 \mathrm{C}(\mathrm{s})(6) \\
\mathrm{Al}_{2} \mathrm{O}_{3}(\mathrm{~s})+\mathrm{MgO}(\mathrm{s}) \rightarrow \mathrm{MgAl}_{2} \mathrm{O}_{4}(\mathrm{~s})
\end{gathered}
$$




\subsubsection{Mg, Si and Metallic Alloys}

According to the literature survey the use of $\mathrm{Mg}$ as anti-oxidant is elaborated in smaller extents. $\mathrm{Mg}$ is considered to be a good anti-oxidant material due the formation of a dense protective layer, but the potential danger of $\mathrm{Mg}$ as the pyrophoric powder, inhibiting the use in industrial environments. Therefore $\mathrm{Mg}$ is most frequently used in the composition Al-Mg. Use of Al-Mg has a superior effect compared to the single use of $\mathrm{Al}$ or $\mathrm{Mg}$ separately. Beside the prevention of carbon oxidation, the alloy also promotes an increase of the mechanical properties when added in combination with $\mathrm{Zr}, \mathrm{SiC}$ and $\mathrm{CaB}_{6}$ in the $\mathrm{MgO}-\mathrm{C}$ refractory bricks [12]. The Si powder has been used successfully in refractory materials [7,9]. At $1200^{\circ} \mathrm{C}$, Si reacts with $\mathrm{C}$ to form $\mathrm{SiC}$ (Equation (8)).

$$
\mathrm{Si}(\mathrm{s})+\mathrm{C}(\mathrm{s}) \rightarrow \mathrm{SiC}(\mathrm{s})
$$

By increasing the temperature, $\mathrm{SiC}$ reacts with the atmospheric nitrogen or $\mathrm{CO}(\mathrm{g})$ forming $\mathrm{Si}_{3} \mathrm{~N}_{4}$ and $\mathrm{SiO}_{2}$ (Equations (9)-(11)). Afterwards, $\mathrm{SiO}_{2}$ will react with the refractory $\mathrm{MgO}$ to form $\mathrm{Mg}_{2} \mathrm{SiO}_{4}$ phase (Equation (11)).

$$
\begin{gathered}
3 \mathrm{SiC}(\mathrm{s})+2 \mathrm{~N}_{2}(\mathrm{~g}) \rightarrow \mathrm{Si}_{3} \mathrm{~N}_{4}(\mathrm{~s})+3 \mathrm{C}(\mathrm{s}) \\
\mathrm{SiC}(\mathrm{s})+2 \mathrm{CO}(\mathrm{g}) \rightarrow \mathrm{SiO}_{2}(\mathrm{~s})+3 \mathrm{C}(\mathrm{s}) \\
\mathrm{SiO}_{2}(\mathrm{~s})+2 \mathrm{MgO}(\mathrm{s}) \rightarrow \mathrm{Mg}_{2} \mathrm{SiO}_{4}(\mathrm{~s})
\end{gathered}
$$

\subsection{Non-Metallic Anti-Oxidants}

The use of non-metallic anti-oxidant materials is frequently associated with liquid phase formation. The liquid phase is formed by these materials reacting with oxygen at high temperatures. The liquid phase acts as pore filling agents and prevents carbon oxidation. However, the formation of these phases causes the degradation of refractory corrosion resistance and mechanical proprieties in the high temperature domain.

\subsubsection{Carbides ( $\mathrm{SiC}, \mathrm{B}_{4} \mathrm{C}, \mathrm{Al}_{8} \mathrm{~B}_{4} \mathrm{C}_{7}, \mathrm{Al}_{4} \mathrm{SiC}_{4}$ )}

$\mathrm{SiC}$ forms the $\mathrm{SiO}_{2}$ phase under oxidative conditions. $\mathrm{The} \mathrm{SiO}_{2}$ phase acts as pore filler above $1500^{\circ} \mathrm{C}$ [6]. The performance of the $\mathrm{SiC}$ as anti-oxidant material is similar to the described mechanisms of $\mathrm{Si}$, as described by Equations (9)-(11). When the amount of $\mathrm{SiC}$ is higher than 5 $\mathrm{wt} \%$, the average durability of $\mathrm{MgO}-\mathrm{C}$ refractories decrease due the extended formation of $\mathrm{SiO}_{2}(\mathrm{~s})$ and thus the corrosion resistance decreases [7].

Anti-oxidant like $\mathrm{B}_{4} \mathrm{C}$, does not act only as oxidant agent preventing $\mathrm{CO}(\mathrm{g})$ formation, but also stimulate formation of a dense oxide layer onto the hot surface of the refractory brick. Thermogravimetric analyses prove the oxidation course in the following sequence: $\mathrm{B}_{4} \mathrm{C}$, carbon, Al-Si, Al, $\mathrm{SiC}$ [13]. Approximately at $1000^{\circ} \mathrm{C}$ $\mathrm{B}_{4} \mathrm{C}$ will react with $\mathrm{CO}(\mathrm{g})$ or $\mathrm{N}_{2}(\mathrm{~g})$ from the atmosphere to form $\mathrm{B}_{2} \mathrm{O}_{3}$ or $\mathrm{BN}$, respectively (Equations (12)-(13)).

$$
\begin{aligned}
& \mathrm{B}_{4} \mathrm{C}(\mathrm{s})+6 \mathrm{CO}(\mathrm{g}) \rightarrow 2 \mathrm{~B}_{2} \mathrm{O}_{3}(\mathrm{l})+7 \mathrm{C}(\mathrm{s}) \\
& \mathrm{B}_{4} \mathrm{C}(\mathrm{s})+2 \mathrm{~N}_{2}(\mathrm{~g}) \rightarrow 4 \mathrm{BN}(\mathrm{s})+\mathrm{C}(\mathrm{s})
\end{aligned}
$$

$\mathrm{B}_{4} \mathrm{C}$ is an effective anti-oxidant and not susceptive to oxidation, however $\mathrm{B}$ is expensive and the formation of liquid phases of $\mathrm{B}_{2} \mathrm{O}_{3}$ and $3 \mathrm{MgO} \cdot \mathrm{B}_{2} \mathrm{O}_{3}$ at high temperatures also decrease the mechanical strength and corrosion resistance of refractories respectively [14].

\subsubsection{Borites ( $\left.\mathrm{ZrB}_{2}, \mathrm{Mg}-\mathrm{B}, \mathrm{CaB}_{6}\right)$}

The effect of the $\mathrm{ZrB}_{2}$ addition in $\mathrm{MgO}-\mathrm{C}$ refractory bricks was mainly studied in the temperature range between $600^{\circ} \mathrm{C}$ and $1200^{\circ} \mathrm{C}$ [15]. Starting from $650^{\circ} \mathrm{C}$ the $\mathrm{ZrB}_{2}$ acts in the $\mathrm{CO}(\mathrm{g})$ reduction, and $\mathrm{ZrO}_{2}, \mathrm{~B}_{2} \mathrm{O}_{3}$ and $\mathrm{C}$ are formed (Equation (14)):

$$
\mathrm{ZrB}_{2}(\mathrm{~s})+5 \mathrm{CO}(\mathrm{g}) \rightarrow \mathrm{ZrO}_{2}(\mathrm{~s})+\mathrm{B}_{2} \mathrm{O}_{3}(1)+5 \mathrm{C}(\mathrm{s})
$$

The oxides formed tend to form a protective layer in the material surface contributing to reduced carbon oxidation. The study of Mg-B addition simultaneously with $\mathrm{Al}$ or $\mathrm{Al}-\mathrm{Mg}$ alloy as anti-oxidant proved the good performance of these materials to inhibit the carbon oxidation and to increase of the rupture modulus of $\mathrm{MgO}-\mathrm{C}$ and $\mathrm{Al}_{2} \mathrm{O}_{3}-\mathrm{C}$ refractories respectively [15]. The $\mathrm{Mg}-\mathrm{B}$ will react with $\mathrm{CO}(\mathrm{g})$ at temperatures higher than $1000^{\circ} \mathrm{C}$ and $\mathrm{B}_{2} \mathrm{O}_{3}(\mathrm{l})$ and $\mathrm{B}_{4} \mathrm{C}(\mathrm{s})$ are formed. The agreed use of $\mathrm{Mg}-\mathrm{B}$ with $\mathrm{Al}$ or $\mathrm{Al}-\mathrm{Mg}$ alloy provides the formation of an oxide layer in the refractory surface consisting of spinel $\mathrm{MgAl}_{2} \mathrm{O}_{4}, \mathrm{MgO}$ and a vitreous phase based of $\mathrm{B}$. The $\mathrm{CaB}_{6}$ addition in the $\mathrm{MgO}-\mathrm{C}$ refractory bricks in presence of $\mathrm{Al}$ and alloy $\mathrm{Al}-\mathrm{Mg}$ also contributes to reduced carbon oxidation and improved material properties. The $\mathrm{CaB}_{6}$ will react with carbon or $\mathrm{CO}(\mathrm{g})$ at temperatures above $1000^{\circ} \mathrm{C}$ to form $\mathrm{CaB}_{2} \mathrm{C}_{2}$ and $\mathrm{CaC}_{2}$, as described for Equations (15) and (16).

$$
\begin{array}{r}
\mathrm{CaB}_{6}(\mathrm{~s})+6 \mathrm{CO}(\mathrm{g}) \rightarrow \mathrm{CaB}_{2} \mathrm{C}_{2}(\mathrm{~s})+2 \mathrm{~B}_{2} \mathrm{O}_{3}(\mathrm{l})+4 \mathrm{C}(\mathrm{s}) \\
\mathrm{CaB}_{2} \mathrm{C}_{2}(\mathrm{~s})+3 \mathrm{CO}(\mathrm{g}) \rightarrow \mathrm{CaC}_{2}(\mathrm{~s})+\mathrm{B}_{2} \mathrm{O}_{3}(1)+3 \mathrm{C}(\mathrm{s})
\end{array}
$$

The oxidation resistance of the $\mathrm{MgO}-\mathrm{C}$ refractory bricks with $\mathrm{CaB}_{6}$ and $\mathrm{Al}$ or $\mathrm{Al}-\mathrm{Mg}$ alloys is improved because a layer of low porosity is formed in the surface of the material. This layer constitutes mainly of $\mathrm{MgO}$ $\mathrm{B}_{2} \mathrm{O}_{3}$ formed from $\mathrm{MgO}$ reaction with $\mathrm{B}_{2} \mathrm{O}_{3}$ [16]. The main benefit of the addition of more than one species of anti-oxidant is the inhibition of carbon oxidation. In some cases these mixtures contribute to the improvement of the refractory corrosion resistance and the thermal shock resistance. However it is still necessary to investigate the relevant mechanisms and performances of these materials in more extended and conclusive studies. 
A factor of concern using those anti-oxidants is the unwanted formation of harmful impurities in the steel, i.e. spinel inclusions [4], resulting from corrosion of single metal/alloys (Al, Si or $\mathrm{Mg}$ ) or carbides or boron based antioxidants (i.e. $\mathrm{CaB}_{6}, \mathrm{~B}_{4} \mathrm{C}, \mathrm{ZrB}_{2}$ ) within steel/slag/refractories interfaces. Another criteria of modern carbon containing refractories suggests increased refractory life, improved refractory stability, reduced refractory wear and reduced carbon content, in order to the implement low $\mathrm{CO}_{2}$-emission refractories [16]. The realization of both approaches within the $\mathrm{MgO}-\mathrm{C}$-system requires the development of suitable $\mathrm{MgO}-\mathrm{C}$ materials combined with metallic anti-oxidants, carbides or borides in consideration of thermodynamic basics [17-23].

\section{Experimental}

\subsection{Polymer Resin Based Foam Replication}

Slurries were made from a mixture of $50 \mathrm{wt} \%$ ethanol and $50 \mathrm{wt} \%$ Novolak resin powder (Bakelite ${ }^{\circledR}$ PF 0227 SP 01, Hexion). The slurry was dispersed in a dissolver (Dispermat N1/SIP, VMA Getzmann GmbH, Germany) without additional additives. The polymeric foam replication process was performed by immersion of 10 pores per inch (PPI) of polyurethane (PU) sponges (ISP GmbH, Limburg, Germany) in the Novolak-Ethanol slurry. The excess slurry was removed using controlled compression in order to improve the distribution of the remaining slurry. Samples were left to dry at room temperature for 12 hours. Heat treatment of the samples was performed in one stage process in an electric tubular furnace in argon.

The stage at $500^{\circ} \mathrm{C}$ holding for 4 hours at a heating rate of $2 \mathrm{~K} / \mathrm{min}$ is for the pyrolysis of the PU polymer superimposed by the transformation of the resin to glassy carbon phase. The as-synthesized samples are designated as "reticulated vitreous carbon (RVC)". Figure 1 shows a draft for the production process. The first step shows the slurry preparation, the step 2 shows the PU foam after the coating process and the step 3 shows the RVC after coating and sinter process.

\subsection{Reticulated Vitreous Carbon Gel-Casting}

The gel-casting solution was prepared with $1.5 \mathrm{wt} \%$ $\mathrm{k}$-carrageen (Koenig \& Wiegand, Germany) used as gelling additive, $1.5 \mathrm{wt} \%$ corn flour (Werz, Germany) as thickening agent, $0.8 \mathrm{wt} \%$ Antiprex A40 (Ciba Inc., Basel, Switzerland) as dispersing agent. $67 \mathrm{wt} \%$ yttria stabilized zirconia (YSZ) or silicon carbide (SiC) solutions were prepared by mixing YSZ or $\mathrm{SiC}$ and additives with de-mineralised water followed by heating at temperature of $80^{\circ} \mathrm{C}$ under atmospheric pressure during 10 min. RVC infiltration of the cellular template foam

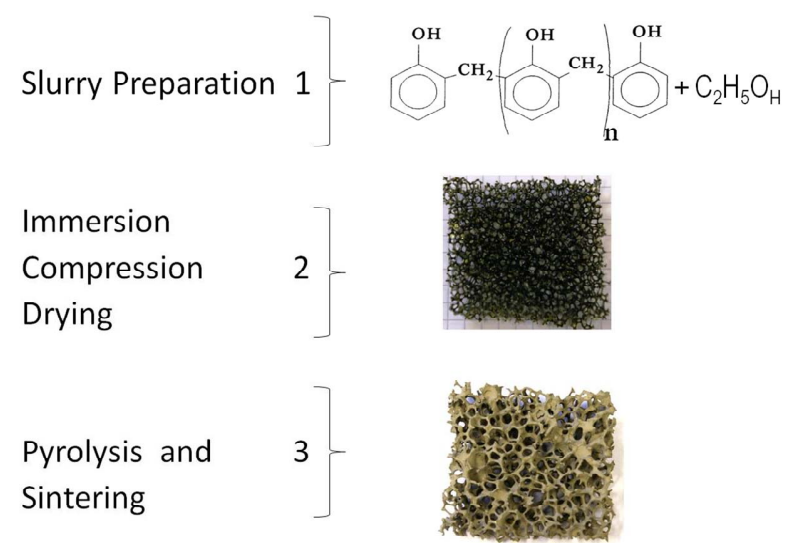

Figure 1. Synthesis scheme of reticulated glassy carbon by polymeric foam replication process.

substrates was performed by the prepared dispersions. The excess solution has been removed by subsequent shaking.

\subsection{Casting of Reinforced MgO-C Composites}

Slurries were made from a mixture of $50 \mathrm{wt} \%$ double distilled water and $50 \mathrm{wt} \%$ magnesium oxide $(\mathrm{MgO})$ (Type TA-3, Lehmann \& Voss \& Co., Hamburg, Germany). The slurry was dispersed in a dissolver without additional additives. The slurries were casted into the open porous RVC-YSZ/SiC reticulated structures and dried at room temperature for 24 hours. The casted samples were sintered at $1400^{\circ} \mathrm{C}$ in argon atmospheres.

\subsection{Sintering Experiments and Microstructures}

Sintering experiments in a high temperature furnace (Thermal Technology Inc., model 1100-3580-W1) at a heating rate of $5 \mathrm{~K} / \mathrm{min}$ and 2 hours dwell time have been performed in argon atmospheres at $1400^{\circ} \mathrm{C}$. The high temperature furnace that is capable of operation in dry inert, reducing and vacuum atmospheres. The Radiation shields are molybdenum or tungsten-molybdenum sheet. The Temperatures is up to $3000^{\circ} \mathrm{C}$ in vacuum, inert and reducing gas atmospheres. The sintering densities were measured by Archimedes principle.

\subsection{Samples Evaluation}

To evaluate the influence of the carbon content and the protective layer four different samples were produced and those samples were compared with a fifth sample (commercial sample). As the aim of this work is to evaluate the thermo mechanical proprieties of the magnesia carbon bricks with a reduced amount of carbon the samples 1 and 2 were produced with half of the carbon content of the commercial sample (6 $\mathrm{wt} \% \mathrm{C})$. The samples 3 and 4 were produce with an intermediary value $(9 \mathrm{wt} \%$ C). The samples produced are showed in Table 1. 
Table 1. Sample produced.

\begin{tabular}{ccc}
\hline & $\% \mathrm{C}$ & Protective layer \\
\hline Sample 1 & $6 \%$ & $\mathrm{SiC}$ \\
Sample 2 & $6 \%$ & $\mathrm{YSZ}$ \\
Sample 3 & $9 \%$ & $\mathrm{SiC}$ \\
Sample 4 & $9 \%$ & $\mathrm{YSZ}$ \\
Sample 5 & $12 \%$ & - \\
(comercial sample) & & - \\
\hline
\end{tabular}

The cold crushing strength, modulus of elasticity and oxidation resistance were measured in fraunhofer institut für zerstörungsfreie prüfverfahren (IZFP) Campus E3.1 Saarbrücken, Germany. The hot modulus of rupture and thermal shock resistance were determined in Department of Materials Science and Engineering (Glass Ceramic) University of Erlangen-Nürnberg.

\subsection{Cold Crushing Strength}

The cold crushing strength was measured according to ASTM C-133 the test specimen sized $65 \times 65 \times 40 \mathrm{~mm}$ have been prepared by wet cutting and were dried at $100^{\circ} \mathrm{C}$. Test specimen sized $65 \times 65 \times 40 \mathrm{~mm}$ have been prepared by wet cutting and were dried at $100^{\circ} \mathrm{C}$. The load at which crack appears in the refractory specimen represents the cold crushing strength of the specimen. The load is applied uniformly on the sample in the flat position.

\subsection{Modulus of Elasticity}

Modulus of elasticity were measured by the ultrasonic method in which the propagation speed of ultrasonic waves was measured along the length samples of the dimension $150 \times 25 \times 25 \mathrm{~mm}$. Briefly, pulses of longitudinal elastic stress waves are generated by an electroacoustical transducer that is held in direct contact with the surface of the refractory under test. After travelling through the material, the pulses are received and converted into electrical energy by a second transducer.

\subsection{Hot Modulus of Rupture}

The modulus of rupture of refractory specimen is determined by measuring the amount of force applied to a rectangular test piece of specific dimensions until failure occurs. This test method covers the determination of the modulus of rupture of carbon-containing refractories at elevated temperatures in air. It was determined according to ASTM C133-7. Each value of hot modulus of rupture is the average over five analyzed test specimens. It was done by three-point bending test using HMOR testing apparatus (Netzsch 422, Germany). The dimensions of all the specimens for hot modulus of rupture characterization were $150 \times 25 \times 25 \mathrm{~mm}$. The specimens were dried at $100^{\circ} \mathrm{C}$ after wet cutting, without prefiring in air atmosphere. The final temperature of $\mathrm{HMOR}$ was $1400^{\circ} \mathrm{C}$ at a heating rate of $5^{\circ} \mathrm{C} / \mathrm{min}$. It was done in air atmosphere with a soaking time of $30 \mathrm{~min}$. Finally, the loading rate of HMOR testing applied in the NETZSCH machine was $0.15 \mathrm{MPa} / \mathrm{s}$.

\subsection{Thermal Shock Resistance}

The thermal shock resistance of refractory materials is determined using standard quench tests in which the material is heated and cooled subsequently and the number of heating \& cooling cycles that a material can withstand prior to failure is taken as its thermal shock resistance. The quantification was done by the number of cycles to withstand such temperature fluctuations. The sample specimen of $30 \times 40 \times 40 \mathrm{~mm}$ were taken and dried at $100^{\circ} \mathrm{C}$ after wet cutting. These samples were heated at $1400^{\circ} \mathrm{C}$ for 10 minutes and then suddenly brought down to ambient condition by cooling it in air for 10 minutes. The number of cycles before any crack in the specimen could be observed was recorded.

\section{Results and Discussion}

\subsection{Microstructural Characterization}

SEM analysis (Figures 2 and 3) shows the RVC after foam replication process and subsequent carbonization and RVC-YSZ after the coating process.

It can not be observed in the Figure 3 the presence of cracks on the coating. The agglomerates are still small enough to flow through the macroporous structure and the solution seemed to be homogeneous.

Since the gel-casted solutions were pseudoplastic in behaviour, the interparticle network and the alignment of the gelling carrageen molecules undergoes a gradual breakdown with increasing shear rate and the typical decrease in viscosity of the gel-casted solutions is observed.

The $\mathrm{MgO}$ suspension is inserted and infiltrated into these cellular structures by slip casting to provide the as delivered green strength, necessary for handling and bricklaying of the masonry. The RVC structure is being transformed into carbon during the steelmaking process. The cellular carbon structure performs the dual role of bonding and non-wetting agent. The RVC-YSZ composite appears as aggregated network of YSZ particles covering uniformly the surface. In some parts of the coating an excess of YSZ coating is observed. High-resolution SEM topographies reveal the absence of cracks. The transformation and carbonization of Novolak resin to vitreous carbon enables the bonding of YSZ particles onto the surface of the template carbon network. The glassy carbon microstructure with a lower state of order of the lattice is not able to compensate excessive stresses by microcracks due to its hardness and brittleness. 


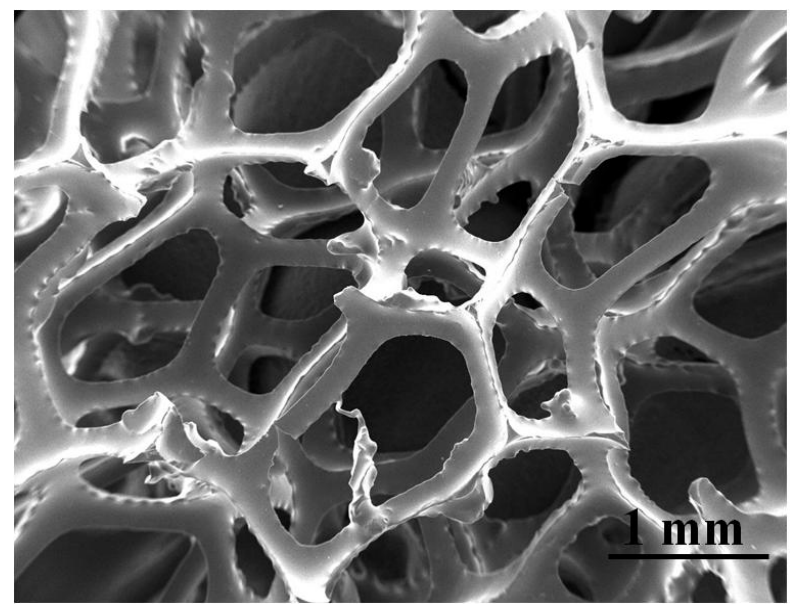

Figure 2. SEM images of cellular glassy carbon networks after the pyrolysis process. The novolak slurry after the pyrolysis formed solid slops, mostly at the struts edges. These slops increase the roughness of the layer and could lead to deformation or even to a structure breakdown during the debinding stage.

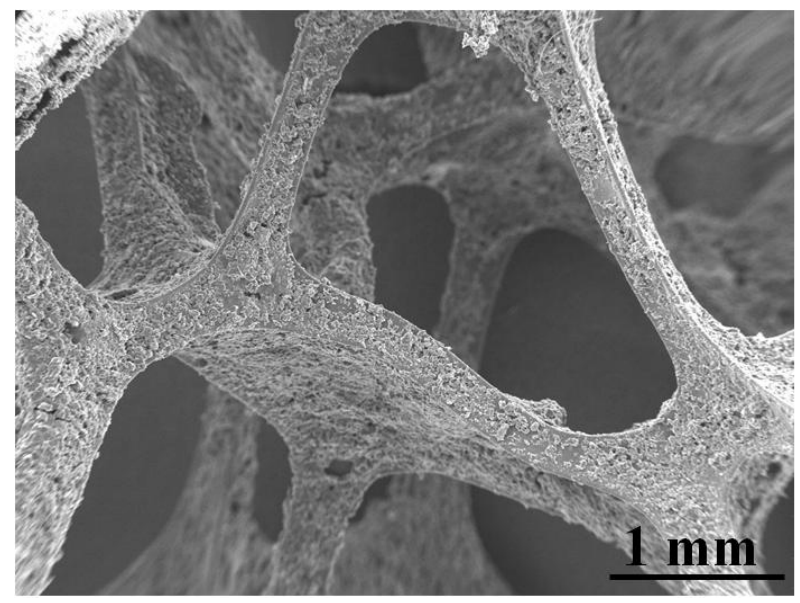

Figure 3. SEM image of RVC-YSZ microstructure indicating the bonding and cementing of YSZ particles into the cellular matrix. The cellular glassy carbon networks was completely coated and the pores were kept opened.

\subsection{Mechanical Proprieties of the Zirconia Foam}

Since the magnesia carbon bricks are exposed particularly to compression stress, it is necessary to have more information about the compression strength. For the compression test 5 samples have been produced with the size of $45 \times 10 \times 5 \mathrm{~mm}$. The compression strength was determinate by a 4 points flexure test machine (MTS810/458). The values can be seen in Table 2.

\subsection{Porosity}

The apparent porosity is shown in Figure 4. Whereas the apparent porosity value for conventional brick is much lower and have a value $10.39 \%$. This is because the
Table 2. Mechanical proprieties of the Zirconia foam.

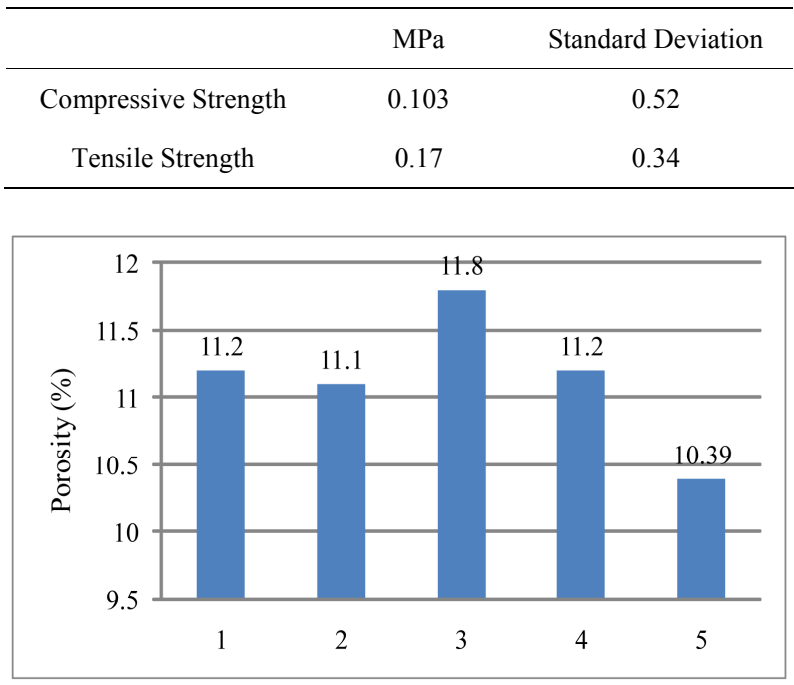

Figure 4. Variation of apparent porosity with the variation of RVC content.

conventional brick contains $10 \mathrm{wt} \%$ graphite. Since graphite works as a filling material it decreases the porosity.

\subsection{Cold Crushing Strength (CCS)}

The variation of cold crushing strength as a function of the amount of RVC and the protective layer is shown in Figure 5. As can be seen from the Figure the CCS values increases linearly with the amount of RVC percentage.

\subsection{Hot Modulus of Rupture (HMOR)}

With the increase of amount of RVC the heating is better distribute, decreasing the thermal tension. This results in a better strength for the open cell carbon foam-magnesia bricks. As the graphite content of conventional brick is much higher so the chances of oxidation of conventional brick are also higher. The oxidation of the conventional brick results in a porous structure in the sample. Thus it reduces the HMOR values as it can be seen in the Figure 6.

\subsection{Modulus of Elasticity (MOE)}

It is clearly showed in Figure 7 with the increase of RVC percentage MOE decreases. As the graphite content increases so due to the compressibility of graphite and RVC, MOE value decreases.

\subsection{Oxidation Resistance}

The average value was taken from four specimens. The change in oxidation resistance is shown in Figure 8. It is expect with the increase of RVC content the percentage 


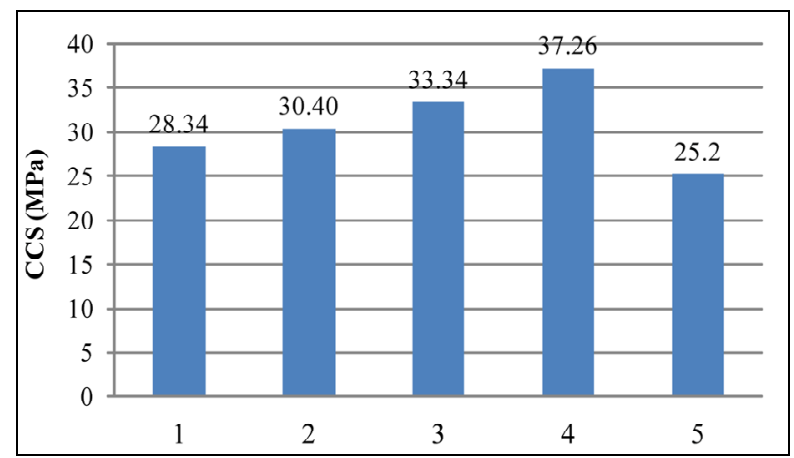

Figure 5. Variation of cold crushing strength with the variation of RVC content.

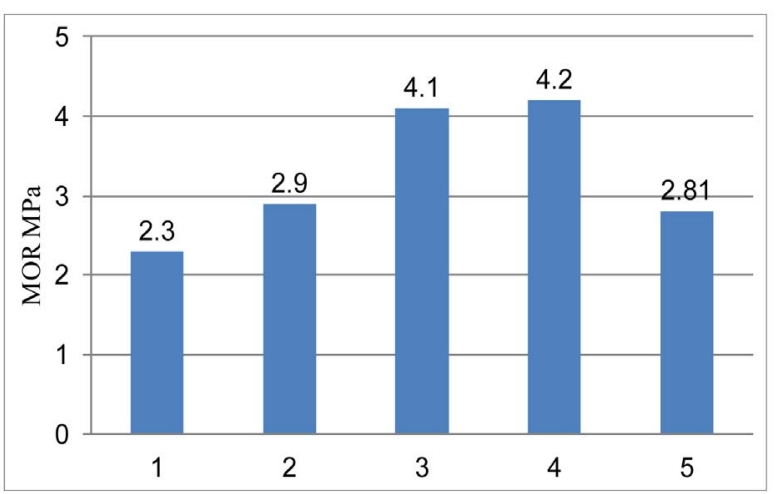

Figure 6. Variation of hot modulus of rupture with the variation of RVC content.

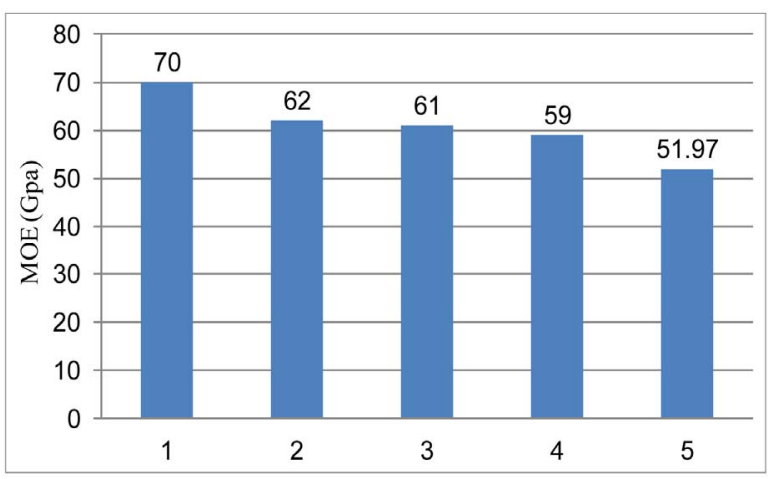

Figure 7. Variation of modulus of elasticity with the variation of RVC percentage.

of oxidation increases, resulting in a poor oxidation resistance. Due the protective layer the oxidation is inferior compared with the Commercial brick. As the commercial brick does not have a protect it presents elevate oxidation rates.

\subsection{Thermal Shock Resistance}

Since RVC percentage increases and the distribution of carbon into the entire matrix increases, an improved thermal shock resistance was achieved as it can been see in Figure 9. This is due to the high surface area and high

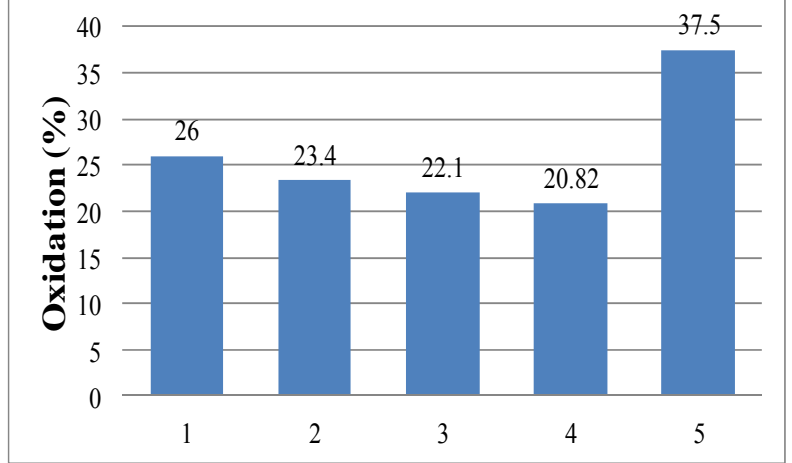

Figure 8. Variation of oxidation resistance with the variation of RVC content.

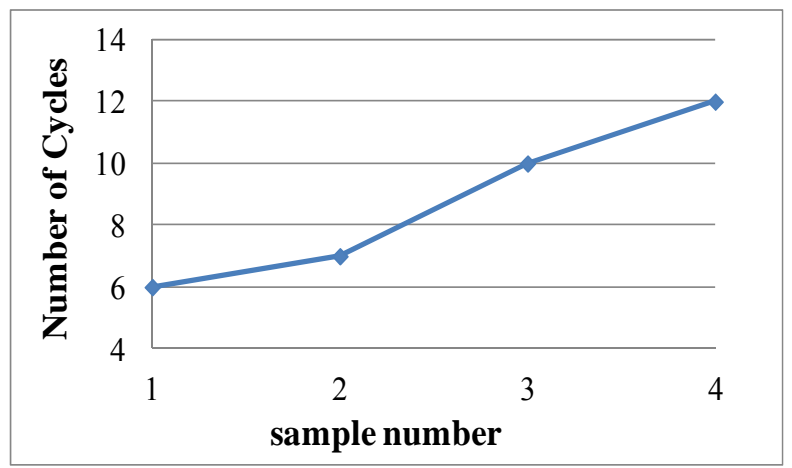

Figure 9. Variation of thermal shock resistance with the variation of RVC content.

volume of carbon. With the increase of RVC content the thermal conductivity of the brick increases, resulting in an elevated thermal shock resistance values. Since we do not receive the data concerning the commercial carbon brick, it was not possible compare the thermal shock resistance.

\section{Conclusions}

The advantages of using cellular functionalized and reinforced carbon structures in high temperature steel processing applications are the flexibility of colloidal processing and ease of variation of processing conditions in order to tailor mechanical properties, thermal shock resistance, thermal mass, thermal conductivity, density, carbon content, specific strength, corrosion and wear resistance in combination with large grained $\mathrm{MgO}$ structures filling the voids of these composite materials. In order to be able to tailor these properties for specific applications yttria stabilized zirconia and silicon carbide as model systems has been deposited onto RVC structures by gel casting process. The microstructures achieved have been investigated and the results are as follows:

1) Nanosized YSZ and silicon carbide particles can be deposited onto the surface of cellular RVC substrates 
by co-immersion/compression.

2) Use of smart reinforcing materials doped in small quantities (i.e. YSZ, SiC) could offer a cost-effective solution for optimized $\mathrm{MgO}-\mathrm{C}$ refractories preventing the slag penetration into the brick microstructure.

3) Mechanical and thermo-mechanical testing show that the $\mathrm{MgO}-\mathrm{C}$ cellular refractory has mechanical proprieties similar with commercial bricks.

For the complete agreement of the mechanisms of reinforcement in high temperature ranges, both analyses, microstructural design and thermodynamics, are necessary. Consequently, the current state of tailoring cellular $\mathrm{C} / \mathrm{YSZ} / \mathrm{SiC}-\mathrm{MgO}$ microstructural characteristics for advanced refractory applications is far from being completed.

\section{Acknowledgements}

This work was performed with financial support of DFGSSP 1418 Feuerfest-Initiative zur Reduzierung von Emissionen-FIRE.

\section{REFERENCES}

[1] E. M. M. Ewais, "Carbon Based Refractories," Journal of the Ceramic Society of Japan, Vol. 112, No. 1310, 2004, pp. 517-532. doi:10.2109/jcersj.112.517

[2] S. Zhang and W. Lee, "Carbon Containing Castables: Current Status and Future Prospects," British Ceramic Transactions, Vol. 101, No. 1, 2002, pp. 1-8. doi:10.1179/096797801125000410

[3] M. Rigaud, "New Additives in Carbon-Bonded Refractories. Ceramic: Charting the Future," Advances in Science and Technology, Vol. 3A, 1995, pp. 399-413.

[4] X. Li, M. Rigaud and S. Palco, "Oxidation Kinects Graphite of Phase in Magnesia-Carbon Refractories," Journal of the American Ceramic Society, Vol. 78, No. 4, 1995, pp. 965-971.

doi:10.1111/j.1151-2916.1995.tb08423.x

[5] A. Yamaguchi, S. Zhang and J. Yu, "Effect of Refractory Oxides on the Oxidation of Graphite and Amorphous Carbon," Journal of the American Ceramic Society, Vol. 79, No. 9, 1996, pp. 2509-2511. doi:10.1111/j.1151-2916.1996.tb09009.x

[6] M. Chen, N. Wang, J. Yu and A. Yamaguchi, "Oxidation Protection of $\mathrm{CaO}-\mathrm{ZrO}_{2}-\mathrm{C}$ Refractories by Addition of SiC," Ceramics International, Vol. 33, No. 8, 2007, pp. 1585-1589.

[7] S. Zhang and W. E. Lee, "Influence of Additives on Corrosion Resistance Corrosion Resistance and Corroded Microstructures of MgO-C Refractories," Journal of the European Ceramic Society, Vol. 21, No. 13, 2001, pp. 2393-2405. doi:10.1016/S0955-2219(01)00208-4

[8] C. G. Aneziris, J. Hubalkova and R. Barabás, "Microstructure Evaluation of MgO-C Refractories with $\mathrm{TiO}_{2}$ and Al-additions," Journal of the European Ceramic Society, Vol. 27, No. 1, 2007, pp. 73-78. doi:10.1016/j.jeurceramsoc.2006.03.001

[9] A. S. Gokce, C. Gurcan, S. Ozgen and S. Aydin, "The Effect of Antioxidants on the Oxidation Behaviour of Magnesi-Carbon Refractory Bricks," Ceramics International, Vol. 34, No. 2, 2008, pp. 323-330. doi:10.1016/j.ceramint.2006.10.004

[10] V. Domiciano, J. R. Garcia and V. C. Pandolfelli, "Water Corrosion Resistance of Metal Powders for Carbon-Containing Castables," American Ceramic Society Bulletin, Vol. 86, No. 1, 2007, pp. 9401-9406.

[11] M. N. Khezrabadi, J. Javadpour, H. R. Rezaie and R. Naghizadeh, "The Effect of Additives on the Properties and Microstructures of $\mathrm{Al}_{2} \mathrm{O}_{3}-\mathrm{C}$ Refractories," Journal of Materials Science, Vol. 41, No. 10, 2006, pp. 3027-3032. doi:10.1007/s10853-006-6770-x

[12] C.-F. Chan, B. B. Argent and W. E. Lee, "Prediction of the Effect Additives on Slag Resistance of $\mathrm{Al}_{2} \mathrm{O}_{3}-\mathrm{SiO}_{2}$ SiC-C Bond Phases in Air," Calphad, Vol. 27, No. 1, 2003, pp. 115-125. doi:10.1016/S0364-5916(03)00036-1

[13] T. R. Lipinski, R. Fichtner and T. Benecke, "Study of the Oxidation Protection of MgO-C Refractories by Means of Boron Carbide," Steel Research, Vol. 63, No. 11, 1992, pp. 493-495.

[14] S. Hayashi, S. Takanaga, H. Takahashi and A. Watanabe, "Behaviour of Boric Compounds Added in MgO-C Bricks," Taikabutsu Overseas, Vol. 11, No. 3, 1991, pp. 12-19.

[15] A. Yamaguchi and H. Tanaka, "Behaviour and Effects of $\mathrm{ZrB}_{2}$ Added to Carbon-Containing Refractories," Taikabutsu Overseas, Vol. 15, No. 2, 1995, pp. 3-9.

[16] O. Volkova, B. Sahebkar, J. Hubalkova, C. G. Aneziris and P. R. Scheller, "Ladle Heating Procedure and Its Influence on the MgO-C-Oxidation," Materials and Manufacturing Processes Vol. 23, No. 8, 2008, pp. 758-763. doi:10.1080/10426910802381975

[17] S. Basu, A. K. Lahiri and S. Seetharaman, "Activity of Iron Oxide in Steelmaking Slag," Metallurgical and Materials Transactions, Vol. 39, No. 3, 2008, pp. 447-456.

[18] A. S. Gokce, C. Gurcan, S. Ozgen and S. Aydin, "The Effect of Antioxidants on the Oxidation Behaviour of Magnesia-Carbon Refractory Bricks," Ceramics International, Vol. 34, No. 2, 2008, pp. 323-330. doi:10.1016/i.ceramint.2006.10.004

[19] S. K. Sadrnezhaad, S. Mahshid, B. Hshemi and Z. A. Nemati, "Oxidation Mechanism of $\mathrm{C}$ in MgO-C Refractory Bricks," Journal of the American Ceramic Society, Vol. 89, No. 4, 2006, pp. 1308-1316. doi:10.1111/j.1551-2916.2005.00863.x

[20] Z. A. Nemati, S. K. Sadrnezhaad and H. R. A. Mooghari, "Effect of Ferrosilicon, Silicon and Aluminium Antioxidants on Microstructure and Mechanical Properties of Magnesia-Graphite Refractory," Refractories Applications and News, Vol. 10, No. 6, 2005, pp. 17-23.

[21] S. Zhang, N. J. Marriott and W. E. Lee, "Thermochemistry and Microstructures of MgO-C Refractories Containing Various Antioxidants," Journal of the European Ceramic Society, Vol. 21, No. 8, 2001, pp. 1037-1047. doi:10.1016/S0955-2219(00)00308-3 
[22] K. Hunold, U. Kross, J. Pötschke, S. Prietzel and M. Thiesen, "RAT-Preventing Erosion in Submerged Nozzles," Ceramic Industry, 2001.

[23] A. R. Studart, U. T. Gonzenbach, E. Tervoort and L. J.
Gauckler, "Processing Routes to Macroporous Ceramics: A Review," Journal of the American Ceramic Society, Vol. 89, 2006, pp. 1771-1789.

doi:10.1111/j.1551-2916.2006.01044.x 